U.S. DEPARTMENT OF THE INTERIOR

U.S. GEOLOGICAL SURVEY

\title{
BRANCH OF PETROLEUM GEOLOGY \\ BIBLIOGRAPHY
}

1993

\author{
SHIRLEY A. OSCARSON \\ COMPILER
}

\section{Open-File Report 94-206}

This report is preliminary and has not been reviewed for conformity with U.S. Geological Survey editorial standards or with the North American Stratigraphic Code. Any use of trade, product, or firm names is for descriptive purposes only and does not imply endorsement by the U.S. Government.

${ }^{1}$ Denver, Colorado 
Agena, W.F., Hutchinson, D.R., Lee, M.W., and Oliver, H.R., 1993, Cape Hatteras to the Mid-Atlantic Ridge--Demultiplexing and archiving a unique multichannel seismic reflection data set: U.S. Geological Survey Open-File Report 93-264, 19 p.

Ahlbrandt, T.S., and Taylor, D.J., 1993, Domestic conventional natural-gas reserves-Can they be increased by the year 2010? in Howell, D.G., ed., The future of energy gases: U.S. Geological Survey Professional Paper 1570, p. 527-546.

Ahlbrandt, T.S., Krohn, K.K., and Curtin, G.C., 1993, Energy and mineral resources in and near NP lands: National Park Service/U.S. Department of the Interior Park Science Bulletin, v. 13, no. 1, p.10-11.

Ahlbrandt, Thomas S. and Downing, Wynn, 1993, Geomorphic, sedimentologic and chronologic analysis of the Opal Dune Field, Lincoln County, Wyoming: U.S. Geological Survey Open-File Report 93-687, 56 p., 1 oversize sheet.

Attanasi, E.D., Bird, K.J., and Mast, R.F., 1993, Economics and the National oil and gas assessment--The case of onshore Alaska: American Association of Petroleum Geologists Bulletin, v. 77, no. 3, p. 491-504.

Baird, J.K., and Dyman, T.S., 1993, Subsurface stratigraphic analysis of Upper Cretaceous rocks, southeastern flank of the Williston basin, North and South Dakota: U.S. Geological Survey Open-File Report 93-335, 20 p.

Balay, R.H., 1993, GKS-PC--A kernel graphics programming system for IBM-PC and compatible microcomputers: U.S. Geological Survey Open-File Report 93-241-A, 52 p.; Open-File Report 93-241-B, Executable program, one 5.25 inch diskette.

Ball, M.M., 1993, Caribbean Plate interactions [abs.]: American Association of Petroleum Geologists/Sociedad Venezuala de Geólogos International Congress and Exhibition, abstracts, v. 77, no. 2, p.305.

Ball, M.M., Dolton, G.L., Mast, R.F., Charpentier, R.R., Henry, M.E., Robinson, Keith, Wandrey, C.J., Crovelli, R.A., Spencer, C.W., and Butler, W.C., 1993, Petroleum geology of the Roswell Resource Area, in Bartsch-Winkler, Susan and Donatich, A.J., eds., Mineral and energy resources of the Roswell Resource Area, east-central New Mexico: U.S. Geological Survey Bulletin 2063, 327 p.

(P) Published Paper; (O) Open-File Report; (A) Abstract; (M) Map 
Barker, C.E., 1993, Implications for organic maturation studies of evidence for a geologically rapid increase and stabilization of vitrinite reflectance at peak temperature--Cerro Prieto geothermal system, Mexico; reply: American Association of Petroleum Geologists Bulletin, v. 77, no. 4, p. 665-673.

Barker, C.E., 1993, Implications for organic maturation studies of evidence for a geologically rapid increase and stabilization of vitrinite reflectance at peak temperature--Cerro Prieto geothermal system, Mexico: Reply: American Association of Petroleum Geologists Bulletin, v. 77, no. 4, p. 673-678.

Barker, C.E., 1993, Calibration of a vitrinite reflectance geothermometer using peak temperature data from fluid inclusions [abs.]: American Chemical Society Abstracts, unpaginated.

Barker, C.E., Bartke, T.C., Hatcher, P.G., and Daws, T.A., 1993, An empirical correlation between coal bed gas with Rock-Eval pyrolysis and ${ }^{13} \mathrm{C}$ NMR results, Cretaceous Mesaverde and Meeteetse Formations, Wind River basin, Wyoming, in Keefer, W.R., Metzger, W.J., and Godwin, L.H., eds., Oil and gas and other resources of the Wind River basin, Wyoming: Wyoming Geological Association Guidebook, Casper, 1993, p. 243-256.

Barker, C.E., and Bone, Y., 1993, A minimal response to contact metamorphism by the Devonian Buchan Group limestones, Buchan Trough,Victoria, Australia--Evidence from impsonite reflectance, isotopic composition and fluid inclusions [abs.]: Society for Organic Petrology, Abstracts with program, v. 10, p. $84-86$.

Barker, C.E., and Crysdale, B.L., 1993, Comparison of predictions from a vitrinite reflectance geothermometer and a kinetic model of vitrinite reflectance evolution--Examples from the Late Cretaceous Mesaverde Formation, Wind River basin, Wyoming [abs.]: Society for Organic Petrology, Abstracts and program , v. 10, p. 43-45.

Barker, C.E., and Crysdale, B.L., 1993, Burial and temperature history of gas generation from coaly organic matter in the Late Cretaceous Mesaverde Formation and associated rocks in the deeper portions of the Wind River basin, Wyoming, in Stroock, B. and Andrew, S., eds., Jubilee Anniversary Field Conference: Wyoming Geological Association, Guidebook, p. 235-258.

Barker, C.E., and Pawlewicz, M.J., 1993, Post-tectonic reheating of portions of the Permian basin as expressed by Iso-Reflectance lines on regional structural sections: New Mexico Geological Society Guidebook, unpaginated.

Barker, C.E., Szmajter, R.J., Daws, R.J., and Threlkeld, C.N., 1993, Rock-Eval pyrolysis data from well cuttings samples, eastern Nevada, collected during 1991: U.S. Geological Survey Open-File Report 93-186, 4 p. 
Barker, C.E., and Pawlewicz, M.J., 1993, An empirical determination of the minimum number of measurements needed to estimate the mean ttanasi, E.D., and Root, D.H. disseminated organic matter: Organic Geochemistry, v. 20 , no. 6, p. 643-651.

Barton, C.C., 1993, Characterizing bedrock fractures in outcrop studies of groundwater hydrology--An example from Mirror Lake, Grafton County, New Hampshire [abs.]: U.S. Geological Survey Open-File Report 93-454, p. 31.

Barton, C.C., 1993, Characterizing fractures in crystalline bedrock for ground-water hydrology studies at Mirror Lake, Grafton, County, New Hampshire [abs.]: Geological Society of America Abstracts with programs, v. 25, no. 6, p. A-425.

Barton, C.C., 1993, Fractal scaling and fluid flow in fracture networks in rock [abs.]: Geological Society of America Abstracts with programs, v. 25, no. 6, p. A-250.

Barton, C.C., and Cortini, Massimo, 1993, Nonlinear forecasting of inflationdeflation patterns in an active caldera (Campi Flegrei, Italy) [abs.]: EOS, Transactions of the American Geophysical Union, v. 74, no. 43, p. 66.

Barton, C.C., Larsen, E., Page, W.R., and Howard, T.M., 1993, Characterizing fractured rock for fluid-flow, geomechanical, and paleostress modeling--Methods and preliminary results from Yucca Mountain, Nevada: U.S. Geological Survey Open-File Report 93-269, 31 p.

Barton, C.C., and Scholz, C.H., 1993, A fractal method for distribution of undiscovered conventional recoverable hydrocarbon accumulations [abs.]: International conference on the complex geometry in nature, Budapest, Hungary, 1993, Abstracts, p. E1.

Barton, C.C., and Scholz, C.H., 1993, The fractal size and spatial distribution of hydrocarbons--Implications for resource assessment and exploration strategy: U.S. Geological Survey Administrative Report, 34 p.

Bird, K.J., 1993, Northern Foothills province (059), in Powers, R.B., ed., Petroleum exploration plays and resource estimates, onshore United States--Region 1, Alaska; Region 2, Pacific Coast: U.S. Geological Survey Bulletin 2034-A, p. A26-A31.

Bird, K.J., 1993, Southern Foothills--Brooks Range province (060), in Powers, R.B., ed., Petroleum exploration plays and resource estimates, onshore United States--Region 1, Alaska; Region 2, Pacific Coast: U.S. Geological Survey Bulletin 2034A, p. A32-A37. 
Bird, K.J., 1993, Arctic Coastal Plain province (058), in Powers, R.B., ed., Petroleum exploration plays and resource estimates, onshore United States--Region 1, Alaska; Region 2, Pacific Coast: U.S. Geological Survey Bulletin 2034-A, p. A8A25.

Blaine, C.C., Edgar, Terence, Ahlbrandt, T.S., and Clayton, J.L., 1993, Paleoclimates and the origin of carbonaceous strata in the Pennsylvanian system of the U.S.A. [abs.]: American Association of Petroleum Geologists 1993 Annual Convention Program, p. 83.

Bohannon, R.G., Grow, J.A., Miller, J.J., and Blank, Jr., H.R., 1993, Seismic stratigraphy and tectonic development of Virgin River depression and associated basins, southeastern Nevada and northwestern Arizona: Geological Society of America Bulletin, v. 105, no. 4, p. 501-520.

Boundy-Sanders, S.Q., Vedder, J.G., Sanders, C.O., and Howell, D.G., 1993, Miocene geologic history of eastern Santa Catalina Island, California, in Hochberg, F.G. and Haaker, P.L., eds., Proceedings of the third California islands symposium: Santa Barbara, California, Santa Barbara Museum of Natural History, p. 3-14.

Burruss, R.C., 1993, Migration of 10's and 100's of Tcf of hydrocarbon and nonhydrocarbon gases from the deep crust--Composition, flux and tectonic setting, in Dyman, T.S., ed., Geologic controls and resource potential of natural gas in deep sedimentary basins in the United States: U.S. Geological Survey Open-File Report 92-524, p. 279-285.

Burruss, R.C., 1993, Oil-water interactions in sediment-hosted ore deposits--Fluid inclusion evidence from five mineralized districts [abs.]: Geological Society of America, Program with abstracts, v. 25, p. A21.

Burruss, R.C., 1993, Stability and flux of methane in the deep crust--a review, in Howell, D.G., ed., The future of energy gases: U.S. Geological Survey Professional Paper 1570, p. 21-30.

Butler, W.C, 1993, A quantitative assessment of five stratigraphic hydrocarbon plays in the Cretaceous and Tertiary strata of Naval Oil Shale Reserve \#3, Piceance basin, Garfield County, northwestern Colorado: U.S. Geological Survey Administrative Report, December 17, 1993, 104 p.

Butler, W.C., 1993, A suggested rationale and selected bibliography for using rulebased expert computer systems (artificial intelligence) in recurrent petroleum resource assessments: U.S. Geological Survey Open-File Report 93-12, 126 p. 
Byrnes, A.P., and Keighin, C.W., 1993, Effects of confining stress on pore throats and capillary pressure measurements, selected sandstone reservoir rocks [abs.]: American Association of Petroleum Geologists 1993 Annual Convention Program, p. 82.

Charpentier, R.R., and Cunningham, K.I., 1993, Fractal structure of Lechuguilla Cave, New Mexico, related to the history of its exploration [abs.]: Geological Society of America, Abstracts with Programs, v. 25, no. 6, p. A413.

Charpentier, R.R., and Sandberg, C.A., 1993, Statistical support for conodont biofacies model for anchoralis-latus zone (Osagean) [abs.]: Geological Society of America, Abstracts with programs, v.25, no. 3, p. 11.

Charpentier, R.R., deWitt, Wallace, Jr., Claypool, G.E., Harris, L.D., Mast, R.F., Megeath, J.D., Roen, J.B., and Schmoker, J.W., 1993, Estimates of unconventional natural gas resources of the Devonian shales of the Appalachian basin, in chap. N of Roen, J.B., and Kepferle, R.C., eds., Petroleum geology of the Devonian and Mississippian black shale of eastern North America: U.S. Geological Survey Bulletin 1909-N, p. N1-N20.

Charpentier, R.R., and Law, B.E., 1993, Estimation of coalbed methane contents from geologic data [abs.]: American Association of Petroleum Geologists 1993 Annual Convention Program, p. 83-84.

Clark, M.S., Lillis, P.G., and Gregory, Glenn, 1993, The Sespe oil fields--A possible kinetic trap with a subthrust source [abs.]: American Association of Petroleum Geologists Bulletin, v. 77, no. 4, p. 693.

Clayton, J.L., 1993, Oil and gas basins in the Former Soviet Union [abs.]: American Association of Petroleum Geologists Bulletin, v. 77, no. 9, p. 1613.

Clayton, J.L., 1993, Composition of crude oils generated from coals and coaly organic matter in shales, in Law, B.E. and Rice, D.D., eds., Hydrocarbons from coal: American Association of Petroleum Geologists Studies in Geology \#38, p. 185201.

Clayton, J.L., Leventhal, J.S., Rice, D.D., Pashin, J.C., Mosher, Byard, and Czepiel, Peter, 1993, Atmospheric methane flux from coals--Preliminary investigation of coal mines and geologic structures in the Black Warrior basin, Alabama, in Howell, D.G., ed., The future of energy gases: U.S. Geological Survey Professional Paper 1570, p. 471-492. 
Clayton, J.L., Ulmishek, G.F., Lillis, P.G., Ball, M.M., Dolton, G.L., Daws, T.A., Mast, R.F., Warden, Augusta, Keller, M.B., Bogino,V.A., Ponznaikovitch, Zinovy, and Jianqiang, Yang, 1993, Petroleum geochemistry and exploration potential of the Pripyat Basin, (USSR) [abs.]: American Association of Petroleum Geologists Annual Convention, New Orleans, 1993, Program, p. 86.

Clayton, J.L., and Jianyu, Chen, 1993, Organic geochemistry of black shale and associated oils of the Pennsylvanian Hermosa Group, Paradox basin, Utah and Colorado [abs.]: American Association of Petroleum Geologists Bulletin, v. 77 , no. 8 , p. 1445 .

Clayton, J.L., and Koncz, I., 1993, Petroleum geochemistry of the Zala Basin, (Hungary)--Early oil generation from carbonate source rocks [abs.]: American Association of Petroleum Geologists Annual Convention, New Orleans, 1993, Program, p. 86.

Clayton, J.L., Warden, Augusta, Daws, T.A., Michael, G.E., Dawson, M.P., and Lillis, P.G., 1993, Organic geochemistry of black shales, marlstones, and oils of Middle Pennsylvanian rocks from the northern Denver and southeastern Powder River basins, Nebraska, and Wyoming: U.S. Geological Bulletin $1917 \mathrm{~K}, 69 \mathrm{p}$.

Collett, T.S., 1993, Natural gas production from Arctic gas hydrates [abs.]: American Association of Petroleum Geologists Bulletin, v. 77, no. 9, p. 1614.

Collett, T.S., 1993, Natural gas hydrates of the Prudhoe Bay and Kuparuk River area, North Slope, Alaska: American Association of Petroleum Geologists Bulletin, v. 77, no. 5., p. 793-812.

Collett, T.S., 1993, Geochemistry of natural gas hydrates [abs.]: American Chemical Society Abstracts of papers, Part 1, Abstract number 81.

Collett, T.S., 1993, Analysis and evaluation of gas hydrate on Alaska's North Slope: Proceedings of the U.S. Department of Energy Fuels Technology Contractors Review Meeting (Agreement No. DE-AI83ML202422), November 16-18, Morgantown, West Virginia, Paper P-11.

Collett, T.S., 1993, Natural gas production from Arctic gas hydrates, in Howell, D.G., ed., The future of energy gases: U.S. Geological Survey Professional Paper 1570, p. 299-312.

Collett, T.S. and Bird, K.J., 1993, Unfrozen, high-salinity intervals within ice-bearing permafrost, North Slope of Alaska, in Proceedings of the Sixth International Conference on Permafrost: International Conference on Permafrost (6th), Beijing, China, 1993, Proceedings, v. 1, p. 94-99. 
Collett, T.S., Bird, K.J., and Magoon, L.B., 1993, Subsurface temperatures and geothermal gradients on the North Slope of Alaska: Cold Regions Science and Technology, v. 21, p. 275-293.

Collett, T.S., and Bird, K.J., 1993, Gas hydrate surface simulating seismic reflector in the Prudhoe Bay-Kuparuk River region of northern Alaska [abs.]: American Association of Petroleum Geologists 1993 Annual Convention Program, p. 87.

Collett, T.S., and Kvenvolden, K.A., 1993, Significance of natural-gas hydrates at the MacKenzie Delta drill site: Nasen Arctic Drilling Program Newsletter "The Nasen Icebreaker," no. 4, p. 1-8.

Collett, T.S., and Kvenvolden, K.A., 1993, Interrelations between gas hydrates of northern Alaska and atmospheric methane [abs.]: U.S. Geological Survey Circular 1086, p. 77-78.

Cortini, Massimo, and Barton, C.B., 1993, Nonlinear forecasting analysis of inflationdeflation patterns of an active caldera (Campi Flegrei, Italy): Geology (Boulder), v. 21, no. 3, p. 239-242.

Crovelli, R.A., 1993, A generalized 20/80 law using probabilistic fractals applied to petroleum field sizes [abs.]: Operations Research Society of America/The Institute of Management Sciences (ORSA/TIMS) Bulletin, no. 36, p. 11.

Crovelli, R.A., 1993, Probability and statistics for petroleum resource assessment: U.S. Geological Survey Open-File Report 93-582, 143 p.

Crovelli, R.A. and Balay, R.H., 1993, LOGRAF--Lognormal graph for resource assessment forecast: U.S. Geological Survey Open-File Report 92-679-A, Documentation (paper copy) 30 p.; Open-File Report 92-679-B, Executable program (5.25" diskette).

Crovelli, R.A., and Barton, C.C., 1993, Fractals and the Pareto distribution applied to petroleum accumulation-size distributions: U.S. Geological Survey Open-File Report 91-18, 26 p.

Dillon, W.P., Fehlhaber, K., and Lee, M.W., 1993, Gas hydrates--Their distribution and significance in sea-floor sediments of the U.S. Atlantic Margin [abs.]: American Association of Petroleum Geologists 1993 Annual Convention, Program, p. 92.

Dillon, W.P., Lee, M.W., Fehlhaber, Kristen, and Coleman, D.F., 1993, Gas hydrates on the Atlantic Continental Margin of the United States--Controls on concentration, in Howell, D.G., ed., The future of energy gases: U.S. Geological Survey Professional Paper 1570, p. 313-330. 
Dillon, W.P., Lee, M.W., and Coleman, D.F., 1993, Controls on distribution of gas hydrate on the Atlantic Continental Margin of the United States [abs.]: American Geophysical Union Transactions, v. 74, no. 43, p. 370.

Dolton, G.L. and Fox, J.E., 1993, Powder River Basin province (101), in Powers, R.B., ed., Petroleum exploration plays and resource estimates, 1989, onshore United States--Region 4, Rocky Mountains and Northern Great Plains: U.S. Geological Survey Open-File Report 93-337, p. 85-116.

Dolton, G.L., Bird, K.J., Varnes, K.L., and Gautier, D.L., 1993, Onshore oil and gas resource assessment areas--Alaska 1993: U.S. Geological Survey Open-File Report 93-331.

Dolton, G.L., Gautier, D.L., Mast, R.F., and Root, D.H., 1993, U.S. Geological Survey estimates of natural-gas energy resources, in Howell, D.G., ed., The future of energy gases: U.S. Geological Survey Professional Paper 1570, p. 495-506.

Dolton, G.L., Varnes, K.L., Gautier, D.L., and Baird, J.K., 1993, Oil and gas resource assessment areas, 1992--Lower 48 States: U.S. Geological Survey Open-File Report 92-696, 1 sheet, scale 1:5,000,000.

Dolton, G.L., and Crovelli, R.A., 1993, Resource assessment methodologies and deep gas resources in Dyman, T.S., ed., Geologic controls and resource potential of natural gas in deep sedimentary basins in the United States: U.S. Geological Survey Open-File Report 92-524, p. 285-295.

Dyman, T.S., 1993, Sweetgrass Arch province (096), in Powers, R.B., ed., Petroleum exploration plays and resource estimates, 1989, onshore United States--Region 4, Rocky Mountains and Northern Great Plains: U.S. Geological Survey Open-File Report 93-337, p. 27-39.

Dyman, T.S., Rice, D.D., Nielsen, D.T., Obuch, R.C., and Baird, J.K., 1993, Geologic and production characteristics of deep oil and gas wells and reservoirs in the conterminous U.S., in Johnson, K.S., Campbell, J.A., eds., Petroleumreservoir geology in the southern Midcontinent: Oklahoma Geological Survey Circular 95, p. 208-215.

Dyman, T.S., Rice, D.D., Schmoker, J.W., Wandrey, C.J., Burruss, R.C., Crovelli, R.A., Dolton, G.L., Hester, T.C., Keighin, C.W., Palacas, J.G., Perry, W.J., Jr., Price, L.C., Spencer, C.W., and Vaughan, D.K., 1993, Geologic studies of deep natural-gas resources in the United States, in Howell, D.G., ed., The future of energy gases: U.S. Geological Survey Professional Paper 1570, p. 171-204. 
Dyman, T.S., Schmoker, J.W., Spencer, C.W., Perry, W.J., Jr., Price, L.C., Palacas, J.G., Dolton, G.L., Burruss, R.C., Keighin, C.W., Hester, T.C., Wandrey, C.J., Vaughan, D.K., Nielsen, D.T., Obuch, R.C., Baird, J.K., and Westcott, P.A., 1993, Geologic controls and resource potential of natural gas in deep sedimentary basins, United States [abs.]: American Association of Petroleum Geologists Annual Convention, New Orleans, 1993, Program, p. 95.

Dyman, T.S., Spencer, C.W., Baird, J.K., Obuch, R.C., and Nielsen, D.T., 1993, Geologic characteristics of deep natural gas resources based on data from significant fields and reservoirs, in Dyman, T.S., ed., Geologic controls and resource potential of natural gas in deep sedimentary basins in the United States: U.S. Geological Survey Open-File Report 92-524, p. 87-112.

Dyman, T.S., Tysdal, R.G., Wallace, C.A., and Lewis, S.E., 1993, Correlation chart of Lower and lower-Upper Cretaceous Blackleaf Formation, eastern Pioneer Mountains, southwestern Montana, to Drummond, central-western Montana [abs.]: American Association of Petroleum Geologists Bulletin v. 77, no. 8, p. 1446.

Dyman, T.S., and Charpentier, R.R., 1993, Measured sections of the Cambrian Sawatch Quartzite and Peerless Formation, and the lower part of the Ordovician Manitou Formation, Manitou Springs area, Front Range of Colorado: U.S. Geological Survey Open-File Report 92-718, 8 p., 1 oversize pl.

Dyman, T.S., ed., 1993, Geologic controls and resource potential of natural gas in deep sedimentary basins in the United States: U.S. Geological Survey OpenFile Report 92-524, 295 p., 9 oversize sheets.

Englund, K.J., Thomas, R.E., and Roen, J.B., 1993, Geology of the Cumberland Gap area, Kentucky, Tennessee, and Virginia [abs.]: American Association of Petroleum Geologists Bulletin, v. 77, no. 8, p. 1468.

Finn, T.M., 1993, Subsurface stratigraphic cross-section of Lower and Upper Cretaceous rocks in the southeastern Wind River basin, Wyoming, in Keefer, W.R., Metzger, W.J., Godwin, Larry H., eds., Oil and gas and other resources of the Wind River basin, Wyoming: Wyoming Geological Association Guidebook, Casper, 1993, p. 91-94.

Flores, R.M. and Keighin, C.W., 1993, Reservoir anisotropy and facies stratigraphic framework in the Paleocene Fort Union Formation, western Wind River basin, Wyoming, in Keefer, W.R., Metzger, W.J., and Godwin, L.H., eds., Oil and gas and other resources of the Wind River basin, Wyoming: Wyoming Geological Association Guidebook, Casper, 1993, p. 121-141. 
Flores, R.M., Clarke, A.C., and Keighin, C.W., 1993, Architecture of Fort Union paleovalley conglomerates related to aquifer potential in the western Wind River basin, in Keefer, W.R., Metzger, W.J., and Godwin, L.H., eds., Oil and gas and other resources of the Wind River basin, Wyoming: Wyoming Geological Association Guidebook, Casper, 1993, p. 143-162.

Fouch, T.D., Collett, T.S., Bird, K.J., Carter, L.D., and Frederiksen, N.O., 1993, The Cretaceous and Tertiary Sagavanirktok Formation, a major exploration target under the North Slope of Alaska and adjacent Beaufort Sea--Preliminary evaluation of exposures at Franklin Bluffs [abs.]: Newsletter of the Rocky Mountain Section SEPM, Rocky Mountain Section SEPM (Society of Sedimentary Geology), v.18, no. 2, p. 1-2.

Fox, J.E., 1993, Stratigraphic cross section A-A' through F-F' showing electric logs of Upper Cretaceous and older rocks, Powder River basin, Montana and Wyoming: U.S. Geological Survey Oil and Gas Investigations Map OC-135.

Fox, J.E., 1993, Stratigraphic cross sections M-M' through R-R', showing electric logs of Upper Cretaceous and older rocks, Powder River basin, Wyoming: U.S. Geological Survey Oil and Gas Investigations Chart OC-137.

Fox, J.E., 1993, Stratigraphic cross section S-S' through V-V' showing electric logs of Upper Cretaceous and older rocks, Powder River basin, Montana and Wyoming: U.S. Geological Survey Oil and Gas Investigations Chart OC-138.

Fox, J.E., and Dolton, G.L., 1993, Bighorn Basin province (013), in Powers, R.B., ed., Petroleum exploration plays and resource estimates, 1989, onshore United States--Region 4, Rocky Mountains and Northern Great Plains: U.S. Geological Survey Open-File Report 93-337, p. 144-160.

Fox, J.E., and Dolton, G.L., 1993, Wind River Basin province (100), in Powers, R.B., ed., Petroleum exploration plays and resource estimates, 1989, onshore United States--Region 4, Rocky Mountains and Northern Great Plains: U.S. Geological Survey Open-File Report 93-337, p. 71-84.

Gautier, D.L., and Brown, R.L., 1993, National Petroleum Council source and supply study--The potential for natural gas in the United States, in Howell, D.G., ed., The future of energy gases: U.S. Geological Survey Professional Paper 1570, p. 507-526.

Gautier, D.L., and Varnes, K.L., comps., 1993, Plays for assessment in Region VIII, Eastern as of October 4, 1993--1995 National Assessment of oil and gas: U.S. Geological Survey Open-File Report 93-596-H, 23 p. 
Gautier, D.L., and Varnes, K.L., comps., 1993, Plays for assessment in Region II, Pacific Coast as of October 4, 1993--1995 National Assessment of oil and gas: U.S. Geological Survey Open File Report 93-596-B, 11 p.

Gautier, D.L., and Varnes, K.L., comps., 1993, Plays for assessment in Region III, Colorado Plateau and Basin and Range as of October 4, 1993--1995 National Assessment of oil and gas: U.S. Geological Survey Open-File Report 93-596-C, $18 \mathrm{p}$.

Gautier, D.L., and Varnes, K.L., comps., 1993, Plays for assessment in Region IV, Rocky Mountains and Northern Great Plains as of October 4, 1993--1995 National Assessment of oil and gas: U.S. Geological Survey Open-File Report 93-596-D, $34 \mathrm{p}$.

Gautier, D.L., and Varnes, K.L., comps., 1993, Plays for assessment in Region VII, Mid-Continent as of October 4, 1993--1995 National Assessment of oil and gas: U.S. Geological Survey Open-File Report 93-596-G, 17 p.

Gautier, D.L., and Varnes, K.L., comps., 1993, Plays for assessment in Region I, Alaska, as of October 4, 1993--1995 National Assessment of oil and gas: U.S. Geological Survey Open-File Report 93-596-A , 7p.

Gautier, D.L., and Varnes, K.L., comps., 1993, Plays for assessment in Region V, West Texas and Eastern New Mexico as of October 4, 1993--1995 National Assessment of oil and gas: U.S. Geological Survey Open-File Report 93-596-E, $9 \mathrm{p}$.

Gautier, D.L., and Varnes, K.L., comps., 1993, Plays for assessment in Region VI, Gulf Coast as of October 4, 1993--1995 National Assessment of Oil and Gas: U.S. Geological Survey Open-File Report 93-596-F, 61 p.

Haeni, F.P., Lane, J.W., Barton, C.C., and Lieblich, D.A., 1993, Fracture detection in crystalline rocks, Mirror Lake area, Grafton County, New Hampshire [abs.]: U.S. Geological Survey Open-File Report 93-454, p. 10.

Hester, T.C., 1993, Trends in sandstone porosity in the Anadarko basin with respect to thermal maturity, in Dyman, T.S., ed., Geologic controls and resource potential of natural gas in deep sedimentary basins in the United States: U.S. Geological Survey Open-File Report 92-524, p. 63-75.

Hester, T.C., and Schmoker, J.W., 1993, Porosity, depth, and thermal maturity data for sandstones of the Anadarko basin, Oklahoma, and other selected locations in the northern hemisphere: U.S. Geological Survey Open-File Report 93-230, $46 \mathrm{p}$. 
Higley, D.K., Takahashi, K.I., and Mast, R.F., 1993, Computer-animated display of oil and gas exploration across the Continental United States: Geobyte, v. 7, no. 6, p. 53-56.

Holm, M.R., Powers, R.B., Dolton, G.L., Law, B.E., Fox, J.E., and Dersch, J.S., 1993, Undiscovered oil and gas resources and leasing status of forest lands in Wyoming, in Stoock, B. and Andrew, S., eds., Jubilee Anniversary Field Conference: Wyoming Geological Association, p. 375-385.

Holm, M.R., Powers, R.B., Dolton, G.L., and Law, B.E., 1993, Leasing status and resource assessment of forest lands in Wyoming--What does the future hold? [abs.]: Wyoming Geological Association, Casper, 1993, unpaginated.

Houghton, J.C. Dolton, G.L., Mast, R.F., Masters, C.D., and Root, D.H., 1993, U.S. Geological Survey estimation procedure for accumulation size distributions by play: American Association of Petroleum Geologists Bulletin, v. 77, no. 3, p. $454-466$.

Howell, D.G., ed., 1993, The future of energy gases: U.S. Geological Survey Professional Paper 1570, 890 p.

Howell, D.G., Bird, K.J., and Gautier, D.L., 1993, Oil--When will we run out?: Earth, v. 2 , no. 2, p. 27-33.

Howell, D.G., Cole, F., Fanelli, M., Wiese, K., 1993, An introduction to "The future of natural gas," in Howell, D.G., ed., The future of energy gases: U.S. Geological Survey Professional Paper 1570, p. 1-12.

Howell, D.G., Cole, Frances, Fanelli, Mike, and Wiese, Katryn, 1993, Natural gas: Earth, v. 2, no. 5, p. 52-59.

Howell, D.G., and Johnsson, M.J., comps., 1993, Abstracts of the International Conference on basin tectonics and hydrocarbon accumulation: International Conference on basin tectonics and hydrocarbon accumulation, Nanjing, China, 1993, 298 p.

Howell, D.G., Wiese, Katryn, and Swinchatt, Jonathon, 1993, The gas gap-Uncertainty in the supply of natural gas, in Howell, D.G., ed., The future of energy gases: U.S. Geological Survey Professional Paper 1570, p. 877-884.

Hsieh, P.A., Shapiro, A.M., Barton, C.C., Haeni, F.P., Johnson, C.D., Martin, C.W., Paillet, F.L., Winter, T.C., and Wright, D.L., 1993, Methods of characterizing fluid movement and chemical transport in fractured rock: Geological Society of America and New England Intercollegiate Geological Conference (85th), Boston, 1993, Guidebook, v. 2, p. R1-R30. 
Hutchinson, D.R., Scholz, C.A., Moore, T.C., Lee, M.W., Colman, S.M., Klitgord, K.D., and Golmshtok, A.J., 1993, Seismic imaging of a gas hydrate layer in Lake Baikal, Siberia [abs.]: Geological Society of America, Abstracts with program , p. A-443.

Isaacs, C.M, 1993, Central Coastal Basins province (078), in Powers, R.B., ed., Petroleum exploration plays and resource estimates, 1989, onshore United States--Region 1, Alaska; Region 2, Pacific Coast: U.S. Geological Survey Bulletin 2034-A, p. 118-121.

Isaacs, C.M., 1993, Santa Maria Basin province (077), in Powers, R.B., ed., Petroleum exploration plays and resource estimates, 1989, onshore United States--Region 1, Alaska; Region 2, Pacific Coast: U.S. Geological Survey Bulletin 2034-A, p. 114-117.

Isaacs, C.M., Medrano, M.D., Siems, D.F., and Mee, J.S., 1993, Abundances of major elements and sedimentary components in cuttings from the Foxen, Sisquoc, Monterey, and Point Sal Formations, OCSP-0315-1 well, Point Arguello oil field, offshore Santa Maria basin, southern California: U.S. Geological Survey Open-File Report 93-382, 35 p.

Isaacs, C.M., Pollastro, R.M., Barron, J.A., Bukry, David, Arends, R.G., Cotton, M.L., Filewicz, M.V., Tomson, J.H., and Lewan, M.D., 1993, Geologic and paleontologic features of CMOGS rock samples (KG-1 to KG-24) from Naples Beach and Lions Head sections [abs]: American Association of Petroleum Geologists Hedberg Conference Abstract Volume, p. 9-18.

Isaacs, C.M., Tomson, J.H., Barron, J.A., Bukry, David and Lewan, M.D., 1993, Preliminary data and age-correlation for extra rock samples (KG-25 to KG-47) in the Cooperative Monterey Organic Geochemistry Study, Santa Maria and Santa Barbara-Ventura basins, California: U.S. Geological Survey Open-File Report 93-0177, 23 p.

Isaacs, C.M., Tomson, J.H., Stewart, K.C., and Jackson, L.L., 1993, Abundances of major elements and sedimentary components in cuttings from the Repetto, Sisquoc, and Monterey Formations, OCS P-0188 H-1 and H-2 wells, Hondo oil field, offshore Santa Barbara-Ventura basin, southern California: U.S. Geological Survey Open-File Report 92-383, 46 p.

Isaacs, C.M., and Rullkotter, Jurgen, 1993, Interlaboratory comparison of CMOGS organic geochemical data [abs.]: American Association of Petroleum Geologists Hedberg Conference Abstract Volume, p. 69-79.

Johnson, R.C., and Rice, D.D., 1993, Composition and origins of shallow $(<1,000 \mathrm{ft})$ coalbed gases, Wind River Reservation, Wyoming: International Pittsburgh Coal Conference, 10th, 1993, Proceedings, p. 1094-1097. 
Johnson, R.C., and Rice, D.D., 1993, Variations in composition and origins of gases from coal bed and conventional reservoirs, Wind River basin, Wyoming [abs.]: Wyoming Geological Association Field Conference, 50th, 1993, Program with abstracts, p. 34 .

Johnson, R.C., and Rice, D.D., 1993, Variations in composition and origins of gases from coal bed and conventional reservoirs, Wind River basin, Wyoming, in Keefer, W.R., Metzger, W.J., Godwin, L.H., eds., Oil and gas and other resources of the Wind River basin, Wyoming: Wyoming Geological Association Guidebook, Casper, 1993, p. 319-335.

Johnson, R.C., Clark, A.C., Barker, C.E., Crysdale, B.L., Higley, D.K., Szmajter, R., and Finn, T.M., 1993, Coalbed methane potential of the Upper Cretaceous Mesaverde and Meeteetse Formations, Wind River Reservation, Wyoming, in Keefer, W.R., Metzger, W.J., and Godwin, L.H., eds., Oil and gas and other resources of the Wind River basin, Wyoming: Wyoming Geological Association Guidebook, Casper, 1993, p. 215-242.

Johnsson, M.J., 1993, A simple model for the system controlling the composition of detrital clastic sediments, in Stratigraphic record of global change: Society of Sedimentary Geology (SEPM), Pennsylvania State College, 1993, Abstracts with program, p. 38.

Johnsson, M.J., 1993, The system controlling the composition of clastic sediments, in Johnsson, M.J., and Basu, A., eds., Processes controlling the composition of clastic sediments: Geological Society of America Special Paper 284, p. 1-19.

Johnsson, M.J., 1993, Unroofing and chemical/mechanical weathering as controls on sandstone composition--The Brookian sequence of northern Alaska, in Stratigraphic record of global change: Society of Sedimentary Geology (SEPM), Pennsylvania State College, 1993, Abstracts with program, p. 19.

Johnsson, M.J., and Basu, A., eds., 1993, Processes controlling the composition of clastic sediments: Geological Society of America Special Paper 284, 342 p.

Johnsson, M.J., Ellen, S.D., and McKittrick, M., 1993, Intensity and duration of chemical weathering: An example from soil clays of the southeastern Koolau Mountains, Oahu, Hawaii, in Johnsson, M.J., and Basu, A., eds., Processes controlling the composition of clastic sediments: Geological Society of America Special Paper 284, p. 147-170.

Johnsson, M.J., Howell, D.G., and Bird, K.J., 1993, Thermal maturity patterns in Alaska--Implications for tectonic evolution and hydrocarbon potential: American Association of Petroleum Geologists Bulletin, v. 77, no. 11, p. 18741903. 
Keighin, C.W., 1993, Pore throats, capillary pressures, porosity, and permeability of clastic reservoirs in the Uinta, Wind River, and Anadarko basins, in Dyman, T.S., ed., Geologic controls and resource potential of natural gas in deep sedimentary basins in the United States: U.S. Geological Survey Open-File Report 92-524, p. 76-85.

Keighin, C.W., 1993, Petrography of some Upper Cretaceous Mesaverde Formation Sandstones, Wind River basin, Wyoming, in Keefer, W.R., Metzger, W.J., and Godwin, L.H., eds., Oil and gas and other resources of the Wind River basin, Wyoming: Wyoming Geological Association Guidebook, Casper, 1993, p. 111119.

Keighin, C.W., Zech, R.S., and Dunbar, R.W., 1993, The Point Lookout Sandstone--A tale of two cores, or petrology, diagenesis, and reservoir properties of Point Lookout Sandstone, Southern Ute Indian Reservation San Juan basin, Colorado: Mountain Geologist, v. 30, no. 1, p. 1-15.

Keighin, C.W., and Flores, R.M., 1993, Petrographic heterogeneity, pore throats, and quality of Tertiary reservoir sandstones, Wind River basin, Wyoming [abs.]: American Association of Petroleum Geologists Annual Convention, New Orleans, 1993, Program, p. 127.

Klett, T.R. and Gautier, D.L., 1993, Methodology for estimating volumes of flared and vented natural gas, in Howell, D.G., ed., The future of energy gases: U.S. Geological Survey Professional Paper 1570, p. 651-660.

Koopmans, M.P., Lewan, M.D., Sinninghe Damste, J.S., and de Leeuw, J.W., 1993, Formation and destruction of sedimentary organically-bound sulphur-Implications for paleoenvironmental reconstruction [abs.]: Geological Society of America Annual Meeting, Boston, 1993, Abstracts with programs, v. 25, no. 6, p. A-20.

Koopmans, M.P., Lewan, M.D., Sinninghe Damste, J.S., and de Leeuw, J.W., 1993, Maturity-related changes in abundance and composition of organic sulphur compounds and sulphur-containing geomacromolecules studied by hydrous pyrolysis [abs.]: International Meeting on Organic Geochemistry, 16th, Stavenger, Norway, 1993, Poster Session, p. 125-128.

Kopaska-Merkel, D.C. and Schmoker, J.W., 1993, Controls on porosity evolution in the Smackover Formation (Upper Jurassic), Alabama [abs.]: American Association of Petroleum Geologists Annual Convention, New Orleans, 1993, Program, p. 131.

Kvenvolden, K.A., and Collett, T.S., 1993, Permafrost and gas hydrates as possible sources of atmospheric methane at high latitudes [abs.]: U.S. Geological Survey Circular 1086, p. 92-93. 
Kvenvolden, K.A., Carlson, P.R., Threlkeld, C.N., and Warden, Augusta, 1993, Possible connection between two Alaskan catastrophes occurring 25 years apart (1964 and 1989): Geology, v. 21, no. 9, p. 813-816.

Law, B.E., 1993, The relationship between coal rank and cleat spacing--Implications for the prediction of permeability in coal: International Coalbed Methane Symposium, Birmingham, 1993, Proceedings, p. 435-441.

Law, B.E., 1993, Nonlinear vitrinite reflectance profiles, eastern United States Gulf Coast [abs.]: American Association of Petroleum Geologists Annual Convention, New Orleans, 1993, Program, p. 135.

Law, B.E., and Rice, D.D., 1993, Coalbed methane--New perspectives on an old source of energy: International Pittsburgh Coal Conference, 10th, 1993, Proceedings, p. 316-319.

Law, B.E., and Rice, D.D., 1993, Preface, in Law, B.E. and Rice, D.D., eds., Hydrocarbons from coal: American Association of Petroleum Geologists Studies in Geology \#38, p. vii-viii.

Law, B.E., and Rice, D.D., eds., 1993, Hydrocarbons from coal: American Association of Petroleum Geologists Studies in Geology \#38, 400 p.

Law, B.E., and Spencer, C.W., 1993, Gas in tight reservoirs--An emerging major source of energy, in Howell, D.G., ed., The future of energy gases: U.S. Geological Survey Professional Paper 1570, p. 233-252.

Lee, M.W., Hutchinson, D.R., Dillon, W.P., Miller, J.J., Agena, W.F., and Swift, B.A., 1993, A method of estimating the amount of in situ gas hydrates in deep marine sediments: Marine and Petroleum Geology, v. 10, no. 5, p. 494-506.

Lee, M.W., Hutchinson, D.R., Dillon, W.P., Miller, J.J., Agena, W.F., and Swift, B.A., 1993, Use of seismic data in estimating the amount of in-situ gas hydrates in deep marine sediment, in Howell, D.G., ed., The future of energy gases: U.S. Geological Survey Professional Paper 1570, p. 563-581.

Lewan, M.D., 1993, Hydrocarbon gas generation from different kerogen types subjected to hydrous pyrolysis: American Chemical Society National Meeting, 206th, Chicago, 1993, Book of Abstracts, Abstract 32.

Lewan, M.D., 1993, Identifying and understanding suppressed vitrinite reflectance through hydrous pyrolysis experiments [abs.]: Society for Organic Petrology, Abstracts and program, v. 10, p. 1-3. 
Lewan, M.D., and Whitney, G.C., 1993, The inhibitory effect of smectite on petroleum expulsion in hydrous pyrolysis experiments [abs.]: American Chemical Society National Meeting, Denver, 1993, Book of abstracts, Abstract no. 58 .

Lund, K., Beard, L.S., and Perry, W.J., Jr., 1993, Relation between extensional geometry of the northern Grant Range and oil occurrences in Railroad Valley, east-central Nevada: American Association of Petroleum Geologists Bulletin, v. 77 , no. 6 , p. $945-962$.

Magoon, L.B., 1993, Preface to a Chinese translation of U.S. Geological Survey Bulletin 2007: Chinese Translation of U.S. Geological Survey Bulletin 2007.

Magoon, L.B., 1993, Bristol Basin province (064), in Powers, R.B., ed., Petroleum exploration plays and resource estimates, 1989, onshore United States--Region 1, Alaska; Region 2, Pacific Coast: U.S. Geological Survey Bulletin 2034-A, p. 46-49.

Magoon, L.B., 1993, Cook Inlet province (067), in Powers, R.B., ed., Petroleum exploration plays and resource estimates, 1989, onshore United States--Region 1, Alaska; Region 2, Pacific Coast: U.S. Geological Survey Bulletin 2034-A, p. 52-57.

Magoon, L.B. and McLean, Hugh, 1993, Alaska Peninsula province (068) in Powers, R.B., ed., Petroleum exploration plays and resource estimates, 1989, onshore United States--Region 1, Alaska, Region 2, Pacific Coast: U.S. Geological Survey Bulletin 2034-A, p. 58-59.

Magoon, Leslie, 1993, Alaska Interior (062), Kandik (part) (061), Interior lowlands (063), and Copper River Basin provinces, in Powers, R.B., ed., Petroleum exploration plays and resource estimates, 1989, onshore United States--Region 1, Alaska; Region 2, Pacific Coast: U.S. Geological Survey Bulletin 2034-A, p. $42-45$.

Magoon, Leslie B., 1993, Kandik province (061), in Powers, R.B., ed., Petroleum exploration plays and resource estimates, 1989, onshore United States--Region 1, Alaska; Region 2, Pacific Coast: U.S. Geological Survey Bulletin 2034-A, p. 38-41.

Masters, C.D., 1993, World resources of natural gas--A discussion, in Howell, D.G., ed., The future of energy gases: U.S. Geological Survey Professional Paper 1570 , p. 607-618.

Masters, C.D., 1993, U.S. Geological Survey petroleum resource assessment procedures: American Association of Petroleum Geologists Bulletin, v. 77, no. 3, p. 452-453. 
McCabe, P.J., Gautier, D.L., Lewan, M.D., and Turner, C., 1993, Public issues in earth sciences, in--Carter, L.M.H., ed., The future of energy gases: U.S. Geological Survey Circular 1115, $58 \mathrm{p}$.

Michaels, G.E., Anders, D.E., and Law, B.E., 1993, Geochemical evaluation of Upper Cretaceous Fruitland Formation coals, San Juan basin, New Mexico and Colorado: Organic Geochemistry, v. 20, no. 4, pp. 475-498.

Miller, J.J., 1993, Program TracePlot, Version 1.1, Seismic trace plotting program for the Macintosh: U.S. Geological Survey Open-File Report 93-5, 19 p.

Miller, J.J., 1993, Program TracePlot, version 2.0; seismic trace plotting program for the Macintosh: U.S. Geological Survey Open-File Report 93-226, 17 p., $1-31 / 2^{\prime \prime}$ disk.

Molenaar, C.M. and Wilson, B.W., 1993, Stratigraphic cross section of Cretaceous rocks along the north flank of the Uinta basin, northeastern Utah, to Rangely, northwestern Colorado: U.S. Geological Survey Miscellaneous Field Investigations Map I-1797-D.

Morton, A.C., and Johnsson, M.J., 1993, Factors influencing the composition of detrital heavy mineral suites in Holocene sands of the Apure drainage basin, Venezuela, in Johnsson, M.J., and Basu, E., eds., 1993, Processes controlling the composition of clastic sediments: Geological Society of America Special Paper 284, p. 171-185.

Newell, K.D., Burruss, R.C., and Palacas, J.G., 1993, Thermal maturation and organic richness of potential petroleum source rocks in Proterozoic Rice Formation, North American Mid-Continent Rift System, Northeastern Kansas:

American Association of Petroleum Geologists Bulletin, v. 77, no. 11, p. 19221941.

Nishenko, S.P., and Barton, C.C., 1993, Scaling laws for natural disasters-Application of fractal statistics to life and economic loss data [abs.]: Geological Society of America Abstracts with programs, v. 25, no. 6, p. A-412.

Nuccio, V.F., Finn, T.M., and Pawlewicz, M.J., 1993, Surface vitrinite reflectance study of the Wind River basin, central Wyoming, in Keefer, W.R., Metzger, W.J., and Godwin, L.H., eds., Oil and gas and other resources of the Wind River basin, Wyoming: Wyoming Geological Association Guidebook, Casper, 1993, p. 307-317.

Nuccio, V.F., and Schmoker, J.W., 1993, Measured and modeled vitrinite reflectance-comparisons in diverse basins [abs.]: American Association of Petroleum Geologists Annual Convention, New Orleans, 1993, Program, p. 159. 
Palacas, J.G., 1993, Source-rock potential of Precambrian rocks in selected basins of the U.S., in Dyman, T.S., ed., Geologic controls and resource potential of natural gas in deep sedimentary basins in the United States: U.S. Geological Survey Open-File Report 92-524, p. 161-172.

Palacas, J.G., Anders, D.E., Flores, R.M., and Keighin, C.W., 1993, Classification of oils, Wind River basin, Wyoming--Useful tool for oil exploration [abs.]: Wyoming Geological Association Field Conference, 50th, Casper, 1993, Program, p. 2.

Palacas, J.G., Flores, R.M., Keighin, C.W., and Anders, D.E., 1993, Organic geochemical typing of oils in the Wind River basin, Wyoming [abs.]: American Association of Petroleum Geologists Annual Convention, New Orleans, 1993, Program, p. 162.

Pawlewicz, M.J., 1993, Vitrinite reflectance and geothermal gradients in the Wind River basin, central Wyoming, in Keefer, W.R., Metzger, W.J., and Godwin, L.H., eds., Oil and gas and other resources of the Wind River basin, Wyoming: Wyoming Geological Association Guidebook, Casper, 1993, p. 295305.

Pearcy, E., and Burruss, R.C., 1993, Hydrocarbons and gold mineralization in the hotspring deposit at Cherry Hill, California, in Parnell, J., Kucha, H., and Landais, P., eds., Bitumens in Ore Deposits: Berlin Heidelberg, Germany, SpringerVerlag, p. 117-137.

Perry, W.J., Jr., 1993, Montana Thrust Belt province (098), in Powers, R.B., ed., Petroleum exploration plays and resource estimates, 1989, onshore United States--Region 4, Rocky Mountains and Northern Great Plains: U.S. Geological Survey Open-File Report 93-337, p. 46-56.

Perry, W.J., Jr., 1993, Southwest Montana province (099), in Powers, R.B., ed., Petroleum exploration plays and resource estimates, 1989, onshore United States--Region 4, Rocky Mountains and Northern Great Plains: U.S. Geological Survey Open-File Report 93-337, p. 57-70.

Perry, W.J., Jr., and Dixon, G.L., 1993, Structure and time of deformation in the central Pancake Range, a geologic reconnaissance, in Gillespie, C.W., ed., Structural and stratigraphic relationships of Devonian reservoir rocks, east central Nevada: Nevada Petroleum Society Field Conference, 1993, Guidebook , p. 123-132.

Perry, W.J., Jr., and Grow, J.A., 1993, Structure and time of deformation in the central Pancake Range, Nye County, Nevada [abs.]: Geological Society of America, Abstracts with programs, v. 25, no. 5, p. 133. 
Perry, W. J., Jr. and LaRock, E.J., 1993, Hydrocarbon potential of the AbsarokaBeartooth Study area--A preliminary summary, in Hammarstrom, J.M., Zientek, M.L., and Elliott, J.E., eds., Mineral resource assessment of the Absaroka-Beartooth study area, Custer and Gallatin National Forests, Montana: U.S. Geological Survey Open-File Report 93-207, p. H1-H6.

Peterson, J.A., 1993, Jurassic sequences of the Western Interior United States-Regional and global associations [abs.]: Canadian Society of Petroleum Geologists International Symposium, Calgary, 1993, Program and abstracts, p. 246.

Peterson, J.A., 1993, Bakken of the north--Product of a global organic "event" and a Devonian-Carboniferous backreef-mound anoxic shelf [abs.]: Canadian Society of Petroleum Geologists International Symposium, Calgary, 1993, Program and abstracts, p. 247.

Peterson, J.A., 1993, Late Paleozoic paleotectonics of the northern Rocky Mountain region [abs.]: Geological Society of America, Abstracts with programs, v. 25, no. 5 , number 5489 .

Peterson, J.A., 1993, Williston Basin province (094), in Powers, R.B., Petroleum exploration plays and resource estimates, 1989, onshore United States--Region 4, Rocky Mountains and Northern Great Plains: U.S. Geological Survey Open-File Report 93-337, p. 11-24.

Peterson, J.A., 1993, Sioux Arch province (095), in Powers, R.B., ed., Petroleum exploration plays and resource estimates, 1989, onshore United States--Region 4, Rocky Mountains and Northern Great Plains: U.S. Geological Survey Open-File Report 93-337, p. 25-26.

Piper, D.Z., Isaacs, C.M., and Medrano, M.D., 1993, Cooccurrence of Fe-, Fe-Ca-, and Ca-phosphate minerals in concretions within the Monterey Formation--A record of uplift of the Santa Maria basin, California, in Keller, M.A., ed., Evolution of sedimentary basins/onshore oil and gas investigations--Santa Maria Province: U.S. Geological Survey Bulletin 1995-C, 15 p.

Piper, D.Z., and Isaacs, C.M., 1993, Micro-element geochemistry of the Monterey Formation, California--Seawater chemistry of deposition [abs.]: American Association of Petroleum Geologists Hedberg Conference Abstract Volume, p. 23-28.

Pitman, J.K., Goldhaber, M.B., Shaw, T.H., and Burruss, R.C., 1993, Basin-scale brine movement in the Midcontinent during the Late Paleozoic--Evidence from the St. Peter Sandstone in the Illinois basin [abs.]: American Association of Petroleum Geologists Bulletin, v. 77, p. 166. 
Pollastro, R.M., 1993, Clay mineralogy, clay content, and diagenesis of deep sandstone reservoirs, Upper Jurassic Norphlet Formation, southwestern Alabama, U.S.A. [abs.]: International Clay Conference, 10th, Adelaide, Australia, 1993, Abstracts, p. P-47.

Pollastro, R.M., 1993, Considerations and applications of the illite/smectite geothermometer in hydrocarbon-bearing rocks of Miocene to Mississippian age: Clays and Clay Minerals, v. 41, no. 2, p. 119-133.

Pollastro, R.M., 1993, Does clay mineralogy determine high porosity in deep Norphlet Formation Sandstones?--an example from southwestern Alabama [abs.]: Clay Minerals Society Program and Abstracts, p. 131.

Pollastro, R.M., and Bohor, B.F., 1993, Origin and clay-mineral genesis of the Cretaceous/Tertiary boundary unit, western interior of North America: Clays and Clay Minerals, v. 41 , no. 1, p. 7-25.

Pollastro, R.M., and Bohor, B.F., 1993, Clay mineralogy, origin, and diagenesis of the Cretaceous/Tertiary boundary unit, Western Interior of North America [abs.]: International Clay Conference, 10th, Adelaide, Australia, 1993, Abstracts, P-46.

Porter, K.W., Dyman, T.S., and Tysdal, R.G., 1993, Sequence boundaries and other surfaces in Lower and Lower-Upper Cretaceous rocks of central and southwestern Montana [abs.]: American Association of Petroleum Geologists Bulletin, v. 77, no. 8, p. 1458.

Porter, K.W., Dyman, T.S., and Tysdal, R.G., 1993, Sequence boundaries and other surfaces in Lower and lower Upper Cretaceous rocks of central and southwest Montana--A preliminary report: Montana Geological Society Field Conference, 1993, Guidebook, p. 45-59.

Potter, C.J., Grow, J.A., and Miller, J.J., 1993, Controls on cross-sectional geometry of extensional basins, east-central Nevada--A seismic stratigraphic approach [abs.]: Geological Society of America, Abstracts with programs, v. 25, no. 5, p. 135.

Powers, R.B., 1993, Introduction, in Powers, R.B., ed., Petroleum exploration plays and resource estimates, 1989, onshore United States--Region 4, Rocky Mountains and Northern Great Plains: U.S. Geological Survey Open-File Report 93-337, p. 1-8.

Powers, R.B., 1993, Geologic framework, in Powers, R.B., ed., Petroleum exploration plays and resource estimates, 1989, onshore United States--Region 4, Rocky Mountains and Northern Great Plains: U.S. Geological Survey Open-File Report 93-337, p. 9-10. 
Powers, R.B., and Varnes, K.L., 1993, Assessed oil and gas plays in Wyoming-Generalized location maps and mean estimates of undiscovered recoverable conventional oil, gas, and natural gas liquids by play appraised in the 1989 National assessment for oil and gas: U.S. Geological Survey Open-File Report 92-192, $43 \mathrm{p}$.

Powers, R.B., ed., 1993, Petroleum exploration plays and resource estimates, 1989, onshore United States; Region 1, Alaska; Region 2, Pacific Coast: U.S. Geological Survey Bulletin 2034-A, 138 p.

Powers, R.B., ed., 1993, Petroleum exploration plays and resource estimates, 1989, onshore United States--Region 3, Colorado Plateau and Basin and Range: U.S. Geological Survey Open-File Report 93-248, 112 p.

Powers, R.B., ed., 1993, Petroleum exploration plays and resource estimates, 1989, onshore United States--Region 4, Rocky Mountains and Northern Great Plains: U.S. Geological Survey Open-File Report 93-337, 116 p.

Powers, R.B., ed., 1993, Petroleum exploration plays and resource estimates, 1989 onshore United States--Region 5, West Texas and Eastern New Mexico: U.S. Geological Survey Open-File Report 93-522, 82 p.

Powers, R.B., ed., 1993, Petroleum exploration plays and resource estimates, 1989, onshore United States--Region 6, Gulf Coast: U.S. Geological Survey OpenFile Report 93-705, 110 p.

Prensky, S., 1993, Recent developments and emerging technology in well logging and formation evaluation--With a selected bibliography: U.S. Geological Survey Open-File Report 93-323, 35 p.

Prensky, S.E., 1993, Recent developments and emerging technology in well logging and formation evaluation with a selected bibliography, in New Technology for the Independent Producer: Technical Transfer Conference, Denver, 1993, p. 1-27.

Prensky, S.E., 1993, Bibliography of well-log applications; annual update October 1, 1992 to September 30, 1993: U.S. Geological Survey Open-File Report 93-0579-A, Documentation (paper copy) 118 p.; Open-File Report 93-0579-B, Executable program (Macintosh version 5.0, 3-1/2" diskette); and Open-File Report 93-0579-C, Executable program (IBM-PC, 3-1/2" diskette).

Prensky, S.E., 1993, Bibliography of well-log applications--Annual update October 1, 1992 to September 30, 1993: The Log Analyst , v. 34, no. 6, p. 37-87. 
Price, L.C., 1993, Thermal stability of hydrocarbons in nature--Limits, evidence, characteristics, and possible controls: Geochimica et Cosmochimica Acta, v. 57, no. 14, p. 3261-3280.

Price, L.C., 1993, C15+ hydrocarbon (HC) thermal destruction as related to high-rank, deep-basin gas resource bases, in Dyman, T.S., ed., Geologic controls and resource potential of natural gas in deep sedimentary basins in the United States: U.S. Geological Survey Open-File Report 92-524, p. 173-277.

Rice, D.D., 1993, Composition and origins of coalbed gas [abs.]: American Association of Petroleum Geologists Annual Convention, New Orleans, 1993, Program, p. 170-171.

Rice, D.D., 1993, Composition and origins of coalbed gas, in Law, B.E., and Rice, D.D., eds., Hydrocarbons from coal: American Association of Petroleum Geologists Studies in Geology \#38, p.159-184.

Rice, D.D., 1993, Controls of coalbed gas composition: International Coalbed Methane Symposium, 1993 Birmingham, Proceedings, v. II, p. 577-588.

Rice, D.D., 1993, Controls on coal-bed gas composition [abs.]: American Association of Petroleum Geologists Bulletin, v. 77, no. 9, p. 1658.

Rice, D.D., 1993, Biogenic gas--Controls, habitats, and resource potential, in Howell, D.G., ed., The future of energy gases: U.S. Geological Survey Professional Paper 1570, p. 583-606.

Rice, D.D., and Ekweozor, C.M., 1993, Occurrence and origin of natural gases, Niger delta, Nigeria [abs.]: American Chemical Society, Book of abstracts, GEOC 53, unpaginated.

Rice, D.D., and Kotarba, Maciej, 1993, Origin of Upper Carboniferous coalbed gases, Lower and Upper Silesian coal basins, Poland: The International Coalbed Methane Symposium, Birmingham, 1993 [Proceedings], v. II, p. 649-658.

Rice, D.D., Law, B.E., and Clayton, J.L., 1993, Coalbed gas--An undeveloped resource, in Howell, D.G., ed., The future of energy gases: U.S. Geological Survey Professional Paper 1570, p. 389-404.

Ryder, R.T., Miller, J.J., Grow, J.A., and Ratcliffe, N.M., 1993, Interpreted reflection seismic events near the North Central Oil Corporation well, Newark basin, Bucks County, Pennsylvania [abs.]: American Association of Petroleum Geologists Bulletin, v. 77, no. 8, p. 1474. 
Sanford, R.F., Pierson, C.T., and Crovelli, R.A., 1993, An objective replacement method for censored geochemical data: Mathematical Geology, v. 25, no. 1, p. 59-80.

Schenk, C.J., 1993, Overview of eolian deposits [abs.], National Park Service Research Conference Proceedings volume, p. 14-15.

Schenk, C.J., Gautier, D.L., Olhoeft, G.R., and Lucius, J.E., 1993, Internal structure of an eolian dune using ground-penetrating radar: International Association of Sedimentologists Special Publication "Aeolian Sediments--Ancient and Modern," p. 61-69.

Schenk, C.J., and Pollastro, R.M., 1993, Reservoir characterization of heavy oil and tar sand reservoirs--An example from the Tertiary of the Uinta basin, Utah [abs.]: American Association of Petroleum Geologists/Sociedad Venezuala de Geólogos International Congress, Abstracts, v. 77, no. 2, p. 347.

Schenk, C.J., and Schmoker, J.W., 1993, Role of halite in the evolution of sandstone porosity, Upper Jurassic Norphlet Formation, Mississippi Salt basin [abs.]: American Association of Petroleum Geologists Bulletin, v. 77, no. 9, p. 1599.

Schenk, C.J., and Schmoker, J.W., 1993, Role of halite in the evolution of sandstone porosity, Upper Jurassic Norphlet Formation, Mississippi Salt basin: Gulf Coast Association of Geological Societies Transactions, v. 43, p. 357-362.

Schenk, C.J., Schmoker, J.W., and Fox, J.E., 1993, Sedimentology of Permian upper part of the Minnelusa Formation, eastern Powder River basin, Wyoming, and a comparison to the subsurface: The Mountain Geologist, v. 30, no. 2, p. 69-78.

Schmoker, J.W., 1993, Distribution of porosity in sedimentary rocks as a function of time-temperature exposure, in Dyman, T.S., ed., Geologic controls and resource potential of natural gas in deep sedimentary basins in the United States: U.S. Geological Survey Open-File Report 92-524, p. 29-62.

Schmoker, J.W., 1993, A systematic context for porosity data [abs.]: American Association of Petroleum Geologists Hedberg Research Conference, Vail, Colo., 1993, Abstracts and programs, unpaginated.

Schmoker, J.W., 1993, Use of formation-density logs to determine organic-carbon content in Devonian shales of the western Appalachian basin and an additional example based on the Bakken Formation of the Williston basin, in Roen, J.B. and Kepferle, R.C., eds., Petroleum geology of the Devonian and Mississippian black shale of eastern North America: U.S. Geological Survey Bulletin 1909-J, p. J1-J14. 
Schmoker, J.W. and Schenk, C.J., 1993, Porosity of the Norphlet Formation (Upper Jurassic), southwestern Alabama and vicinity [abs.]: American Association of Petroleum Geologists Annual Convention, New Orleans, 1993, Program, p. 178.

Schmoker, J.W., and Travisono, Jeanne, eds., 1993, Summary of "The Mountain Geologist" reader survey: The Mountain Geologist, v. 30, no.1, p. 1-3.

Shurr, G.W., Wosick, F.D., and Rice, D.D., 1993, Regional pressure patterns as evidence for fractured reservoirs in the Bowdoin and Phillips Sandstones on Bowdoin Dome, Montana, in Energy \& mineral resources of central Montana: Montana Geological Society, 1993 [Guidebook], p. 117-127.

Spencer, C.W., 1993, Uinta-Piceance-Eagle Basins province (086), in Powers, R.B. , ed., Petroleum exploration plays and resource estimates, 1989, onshore United States--Region 3, Colorado Plateau and basin and range: U.S. Geological Survey Open-File Report 93-248, p. 35-45.

Spencer, C.W., and Wandrey, C.J., 1993, Deep gas reservoir pressure and initial potential test data, in Dyman, T.S., ed., Geologic controls and resource potential of natural gas in deep sedimentary basins in the United States: U.S. Geological Survey Open-File Report 92-524, p. 117-147.

Stanley, R.G., 1993, Western Oregon-Washington province (072), in Powers, R.B., ed., Petroleum exploration plays and resource estimates, 1989, onshore United States--Region 1, Alaska; Region 2, Pacific Coast: U.S. Geological Survey Bulletin 2034-A, p. 72-75.

Stanley, R.G., Valin, Z.C., and Pawlewicz, M.J., 1993, Rock-Eval pyrolysis and vitrinite reflectance results from lower Miocene strata in the onshore Santa Maria basin and Santa Barbara coastal area, California [abs.]: American Association of Petroleum Geologists Bulletin, v. 77, no. 4, p. 716-717.

Sweeney, J.J., Barker, C.E., and Bostick, N.H., 1993, Implications for organic maturation studies of evidence for a geologically rapid increase and stabilization of vitrinite reflectance at peak temperature--Cerro Prieto geothermal system, Mexico; discussion and reply: American Association of Petroleum Geologists Bulletin, v. 77, no. 4, p. 665-678.

Swift, Ann, Dillon, William, and Lee, Myung, 1993, The Florida Cretaceous Carbonate Platform [abs.]: American Association of Petroleum Geologists Annual Convention, New Orleans, 1993, Program, p. 188. 
Taylor, D.J., and Huffman, A.C., Jr., 1993, Ute Mountain Ute Indian Reservation of southwestern Colorado and northwestern New Mexico--Subsurface evaluation using multichannel seismic reflection data: U.S. Geological Survey Administrative Report, $37 \mathrm{p}$.

Tennyson, M.E., 1993, Eastern Oregon-Washington province (081), in Powers, R.B., ed., Petroleum exploration plays and resource estimates, 1989, onshore United States--Region 1, Alaska; Region 2, Pacific Coast: U.S. Geological Survey Bulletin 2034-A, p. 130-133.

Tennyson, M.E., and Beeman, W.R., 1993, Preliminary 1:100,000-scale geologic map of Santa Maria 30' x 60' quadrangle, California--A digital compilation in progress [abs.]: American Association of Petroleum Geologists Bulletin, v. 77, no. 4, p. 718.

Tennyson, M.E., and Isaacs, C.M., 1993, U.S. Geological Survey National assessment of oil and gas resources--Pacific region onshore and State offshore [abs.]: American Association of Petroleum Geologists Bulletin, v. 77, no. 4, p. 718.

Tennyson, M.E., Johnson, S.Y., Niem, A.R., and Niem, W.A., 1993, U.S. Geological Survey National Assessment of oil and gas resources--Pacific Northwest, onshore and state offshore [abs.]: Northwest Petroleum Association Annual Symposium, Bend, Oregon, Handout, 1993.

Tuttle, M.L., Breit, G.N., and Klett, T.R., 1993, Environments of black-shale deposition in a restricted marine basin--Interpretation of carbon-sulfur systematics, $\mathrm{d}^{34} \mathrm{~S}$, and trace-metal enrichment [abs.]: Geological Society of America Abstracts with programs, v. 25, no. 6, p. A-240.

Tuttle, M.L., Klett, T.R., and Richardson, M., 1993, Geochemical processes controlling sulfur, carbon, and metals in Pennsylvanian source rocks of the Paradox basin, Utah and Colorado [abs.]: American Association of Petroleum Geologists Bulletin, v. 77, no. 8, p. 1462.

Ulmishek, G.F., 1993, Geology and exploration potential of major petroleum basins in the Former USSR [abs.]: American Association of Petroleum Geologists Bulletin, v. 77, no. 11, p. 2022.

Ulmishek, G.F., 1993, Geology and hydrocarbon resources of onshore basins in eastern China: U.S. Geological Survey Open-File Report 93-4, 156 p.

Ulmishek, G.F., and Masters, C.D., 1993, Oil, gas resources estimated in the former Soviet Union: Oil and Gas Journal, v. 91, no. 50, p. 59-62.

Ulmishek, G.F., and Masters, C.D., 1993, Estimated petroleum resources in the former Soviet Union: U.S. Geological Survey Open-File Report 93-316 , 19 p. 
Ulmishek, G.F., Charpentier, R.R., and Barton, C.C., 1993, The global oil system--The relationship between oil generation, loss, half-life, and the world crude oil resource; discussion and reply: American Association of Petroleum Geologists Bulletin, v. 77, no. 5, p. 896-902.

Varnes, D.J., Smith, W.K., Savage, W.Z., and Varnes, K.L., 1993, Control and deformation surveys at the Slumgullion Slide, Hinsdale County, Colorado--A progress report: U.S. Geological Survey Open-File Report 93-577 , 15 p.; one oversize map, scale 1:2000.

Wandrey, C.J., and Vaughan, D.K., 1993, Maps illustrating the distribution of deep wells in the U.S. by geologic age, in Dyman,T.S., ed., Geologic controls and resource potential of natural gas in deep sedimentary basins in the United States: U.S. Geological Survey Open-File Report 92-0524, p. 114-116.

Wesley, J.B., Wandrey, C.J., and Fouch, T.D., 1993, Principal drill stem test database (UBDST) and documentation--Analysis of Uinta basin, Utah gas-bearing Cretaceous and Tertiary strata: U.S. Geological Survey Open-File Report 93193, 19 p.; one 3-1/2 inch diskette.

Wiggins, W.D., Harris, P.M., and Burruss, R.C., 1993, Geochemistry of post-uplift calcite in the U.S. Permian basin: Geological Society of America Bulletin, v. 105 , p. $779-790$.

Zech, R.S. and Keighin, C.W., 1993, Porosity and permeability data for the Point Lookout Sandstone from core holes IHCMS and 2HCMS, northern San Juan basin, La Plata County, Colorado: U.S. Geological Survey Open-File Report 93-306, $180 \mathrm{p}$.

Zihlman, F.N., 1993, DUMPSEGY V1.0--A program to examine the contents of SEG-Y disk-image seismic data: U.S. Geological Survey Open-File Report 92$590,20 \mathrm{p}$.

Zihlman, F.N. and Ambroziak, R.A., 1993, National Energy Research Seismic Library, processed seismic data for 29 lines in the National Petroleum Reserve in Alaska: U.S. Geological Survey Digital Data Series DDS-0005, one CDROM.

Zihlman, F.N. and Pantea, M.P., 1993, USGS explores CD-ROM technology: Geotimes, v. 38, no. 7, p. 17-19.

Zihlman, F.N., Abston, C.C., Taylor, D.J., Agena, W.F., and Oliver, H.L., 1993, International phase of ocean drilling--Demultiplexed seismic data, Cape Hatteras to Mid-Atlantic Ridge: Digital Data Series 13 (CD-ROM). 
Zihlman, F.N., comp. and ed., 1993, Deep seismic reflection studies in the Pacific Northwest, United States: U.S. Geological Survey Open-File Report 92-714, CD-ROM. 